\title{
Marine bacterial, archaeal and eukaryotic diversity and community structure on the continental shelf of the western Antarctic Peninsula
}

\author{
Catherine M. Luria' ${ }^{1,2}$, Hugh W. Ducklow ${ }^{3}$, Linda A. Amaral-Zettler ${ }^{1,2,4, *}$ \\ ${ }^{1}$ Department of Ecology and Evolutionary Biology, Brown University, Providence, Rhode Island 02912, USA \\ ${ }^{2}$ The Josephine Bay Paul Center for Comparative Molecular Biology and Evolution, Marine Biological Laboratory, \\ Woods Hole, Massachusetts 02543, USA \\ ${ }^{3}$ Lamont-Doherty Earth Observatory of Columbia University, Palisades, New York 10964, USA \\ ${ }^{4}$ Department of Earth, Environmental and Planetary Sciences, Brown University, Providence, Rhode Island 02912, USA
}

\begin{abstract}
The classic view of polar ocean foodwebs emphasizes large predators sustained by energy and material flow through short, efficient diatom-krill-predator food chains. Bacterial activity is generally low in cold polar waters compared to that at lower latitudes. This view appears to be changing, with new studies of microbial foodwebs in Arctic and Antarctic oceans. We characterized bacterial, archaeal, and eukaryotic community diversity and composition from 2 depths (near surface and below the euphotic zone) at 4 sites, including the inshore and offshore, and north and south corners of a sampling grid along the western coast of the Antarctic Peninsula (WAP). We detected up to 2-fold higher richness in microbial eukaryotes at surface and deep inshore northern stations as compared to southern stations, but offshore northern and southern stations revealed either no trend or higher richness at depth in the south. In contrast, bacterial and archaeal richness showed no significant differences either inshore or offshore at northern versus southern extents, but did vary with depth. Archaea were virtually absent in summer surface waters, but were present in summer deep and winter surface samples. Overall, winter bacterial and archaeal assemblages most closely resembled summer sub-euphotic zone assemblages, reflecting well-established seasonal patterns of water column turnover and stratification that result in an isolated layer of 'winter water' below the euphotic zone. Inter-domain heterotrophphototroph interactions were evident from network analysis. The WAP is among the most rapidly warming regions on earth. Our results provide a baseline against which future change in microbial communities may be assessed.
\end{abstract}

KEY WORDS: Antarctica $\cdot$ MIRADA-LTERS $\cdot$ Palmer LTER $\cdot$ Pyrosequencing $\cdot$ V6 $\cdot$ V9 $\cdot$ Microbial oceanography

\section{INTRODUCTION}

Microbes are the most abundant organisms in the biosphere, and their activities determine many biogeochemical properties of marine ecosystems (Azam et al. 1983, Pomeroy et al. 2007). Characterizing microbes in the environment has historically proven difficult due to their small size and vast diversity, but recent advances in sequencing technology have allowed for great advances in efforts to describe microbial community structure and function (DeLong \& Karl 2005, Sogin et al. 2006, Frias-Lopez et al. 2008, Yooseph et al. 2010). Evidence is mounting that microbial community composition is sensitive to environmental variability. For example, recent findings demonstrate that water mass physical and 
chemical, as well as biological, properties drive microbial community structure (Agogué et al. 2011). However, basic information on microbial community structure is still scarce for many areas of the global ocean.

Our study was part of the Microbial Inventory Research Across Diverse Aquatic Long Term Ecological Research Sites (MIRADA-LTERS) Project (http://amarallab.mbl.edu). The LTER Network of 25 aquatic (marine and freshwater) and terrestrial sites is a rich resource for comparative study of microbial communities and the processes they catalyze (Robertson et al. 2012, Alber et al. 2013). The Palmer Antarctica LTER study region is a pelagic marine ecosystem, with ongoing research examining the impacts of seasonal to inter-annual climate variation on sea ice, plankton food webs, and ecosystem biogeochemistry (Ducklow et al. 2012a). Our study region extends $\sim 200 \mathrm{~km}$ from the coast to the open ocean and $\sim 400 \mathrm{~km}$ from north to south and encompasses several subregions, each with its own combination of potential forcing factors on microbial communities (Ducklow et al. 2012b).

Like other high-latitude areas, the western coast of the Antarctic Peninsula (WAP) experiences extreme seasonal variations, ranging from near total darkness, deep vertical mixing, extensive sea ice cover, and minimal photosynthetic organic matter formation in winter, to the opposite conditions in summer. Bacterial abundance and productivity increase from winter to summer as primary production increases and the water warms from the freezing point $\left(-1.8^{\circ} \mathrm{C}\right)$ to about 0 to $+2^{\circ} \mathrm{C}$ (Ducklow et al. 2012b). Bacterial diversity is high in cold, dark, lowproductivity waters in winter, and much lower in summer (Murray \& Grzymski 2007, Grzymski et al. 2012). In summer (January) 2008, we sampled the 4 corners of the Palmer LTER study grid (Fig. 1) in order to contrast highly productive inshore sites with less productive offshore sites and to compare northern and southern sites differing in the annual extent and duration of sea ice cover.
We sampled and described all 3 domains of microbial life-Eukarya, Bacteria, and Archaeathrough small subunit (SSU) rRNA gene hypervariable amplicon sequencing in order to investigate spatio-temporal variation within domains and the linkages between microbial trophic levels. We found evidence of vertical stratification and temporal variation in community structure corresponding to the seasonal evolution of the upper water column. There were few differences between northern and southern sites. Significant variation between northern and southern assemblages was only evident for microbial eukaryotes and not for their bacterial and archaeal counterparts. These results provide core data for comparative study with other aquatic systems, and furnish a baseline against which future changes may be assessed on a range of time and space scales.

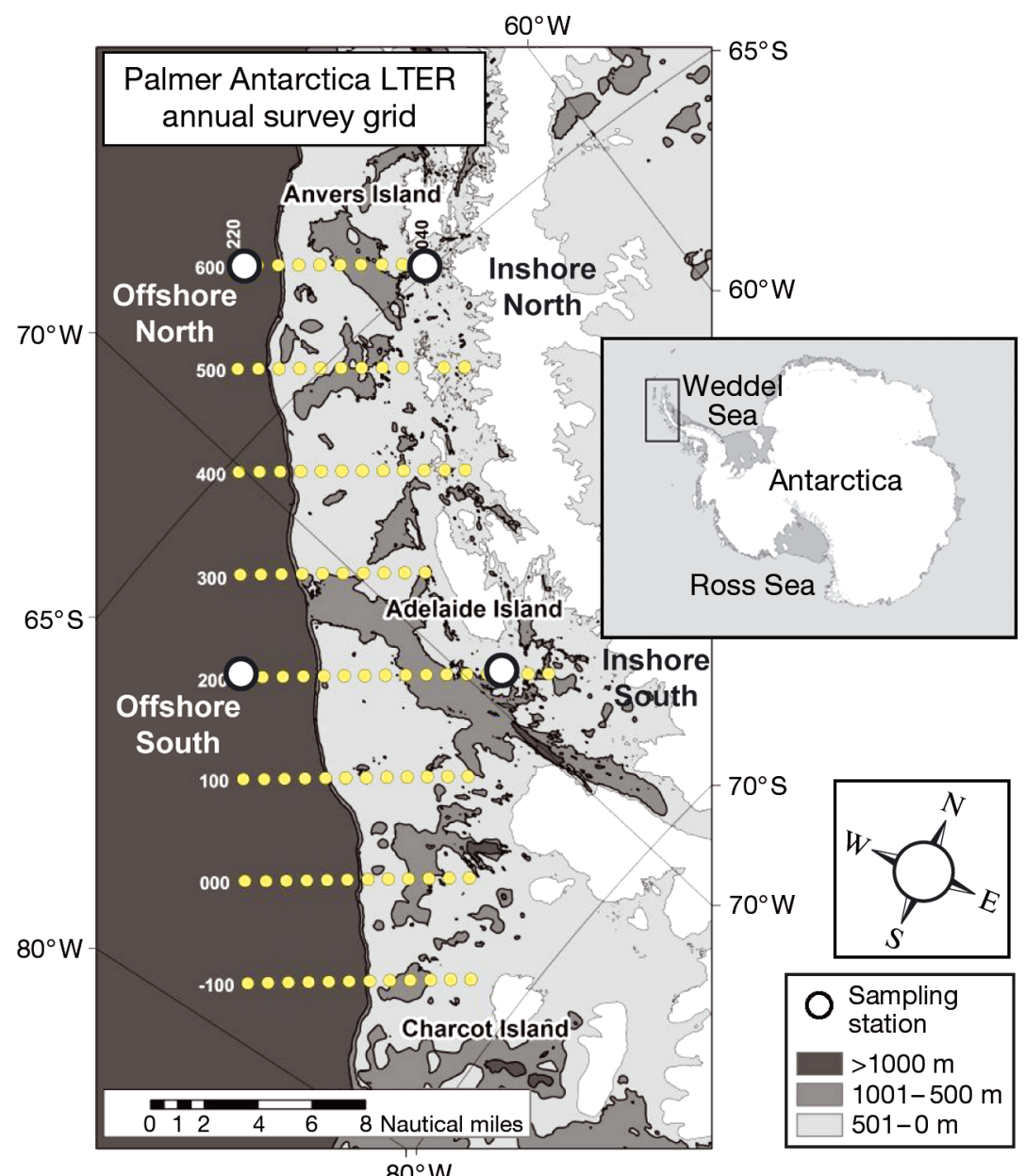

Fig. 1. Palmer LTER study region along the western Antarctic Peninsula. White circles indicate sampling sites; yellow circles show the cruise track for the grid. Land is shown in white; shades of gray indicate depths of water offshore, according to the key; and numbers along the sampling grid correspond to LTER designated sampling names 


\section{MATERIALS AND METHODS}

\section{Sample collection and processing}

Sampling was conducted on the annual Palmer LTER midsummer research cruise (January-February 2008). We drew samples from 10 and $100 \mathrm{~m}$ depths from the northern and southern, inshore and offshore corners of the Palmer LTER sampling grid that lies along the western coast of the Antarctic Peninsula (Fig. 1). We collected duplicate samples using a rosette equipped with 101 Niskin bottles and conductivity, temperature, and depth (CTD) probes. To contrast summer and winter water, we also collected an additional Austral winter sample from $10 \mathrm{~m}$ depth at the northern, inshore sampling site in August 2008, using a submersible pump with silicone tubing. Environmental data - including nitrate $\left(\mathrm{NO}_{3}\right)$, phosphate $\left(\mathrm{PO}_{4}\right)$, silicate $\left(\mathrm{SiO}_{4}\right)$, particulate nitrogen $(\mathrm{PN})$, total nitrogen $(\mathrm{TN})$, particulate organic carbon (POC), dissolved organic carbon (DOC), chlorophyll a $(\mathrm{chl} \mathrm{a}),{ }^{14} \mathrm{C}$-primary production, and bacterial abundance and production - were collected through the Palmer Station LTER (http://ocean informatics.ucsd.edu/datazoo/data/pallter/datasets). Protocols for these measurements are available in the metadata for each environmental variable. Limited environmental data were available for the winter sample.

We filtered water samples (1 to $2 \mathrm{l}$ ) through $0.2 \mu \mathrm{m}$ Sterivex ${ }^{\mathrm{TM}}$ filters (Millipore), preserved genomic DNA by flooding the $2 \mathrm{ml}$ filter cartridge reservoir with sucrose lysis buffer (40 mM EDTA, $50 \mathrm{mM}$ Tris- $\mathrm{HCl}$, $0.75 \mathrm{M}$ sucrose), and stored the filters at $-80^{\circ} \mathrm{C}$ until processing. We extracted DNA using a Puregene DNA extraction kit (Qiagen), with modifications as described by Amaral-Zettler et al. (2009), and stored the DNA at $-20^{\circ} \mathrm{C}$ until PCR amplification. Bacterial and archaeal V6 16S rRNA and eukaryotic V9 18S rRNA gene hypervariable regions were amplified as described previously (Huber et al. 2007, AmaralZettler et al. 2009), using 'barcoded' primers which allowed for multiplexed sequencing (see http://vamps. mbl.edu/resources/primers.php for details). For each sample, we pooled triplicate $50 \mu \mathrm{l}$ PCR reaction products to minimize propagation of PCR errors and purified them using a QIAquick column-based purification kit (Qiagen). We sequenced purified amplicons on a 454 Genome Sequencer FLX (Roche) according to the manufacturer's protocols using the LR70 kit. We trimmed and filtered raw sequence reads as previously described (Huse et al. 2007). Briefly, 5 bp barcodes were detected and removed, if exact matches to the barcode were not recovered these reads were discarded. Further quality filtering was achieved by requiring exact matches to the proximal and distal primers, and removal of any reads with ambiguous bases or $<50$ nucleotides in length. We assigned operational taxonomic units (OTUs) at a $3 \%$ (Bacteria and Archaea) or 6\% (Eukarya) sequence clustering level (SLP-PWAL; Huse et al. 2010). We chose a more conservative cut-off for eukaryotic clustering to accommodate microheterogeneities existing in many eukaryotic taxa. In many cases, we were able to achieve genus-level identifications with this cluster width. We also removed all metazoan OTUs from downstream analyses.

\section{Alpha and beta diversity estimation}

We determined parametric modeling-based estimates of species richness for Bacteria and Archaea using the CatchAll program (Bunge 2011) and estimated eukaryotic richness using the non-parametric Chao2 estimator in SPADE (Chao \& Shen 2010). For multivariate methods, we employed bacterial and archaeal abundance matrices, while eukaryotic abundances were converted to incidence-based (presence/absence) matrices. PC-ORD (Peck 2010) was used to conduct 2-way cluster analysis for the archaeal dataset. We generated Morisita-Horn similarity indices for Bacteria and Archaea in EstimateS (Colwell 2009) and employed Jaccard similarity indices for eukaryotic data in Primer-E (v6, Plymouth, UK). Bray-Curtis and Morisita-Horn similarity indices were generated for resampled bacterial and archaeal data sets. SIMPROF (Primer-E) analyses allowed us to test for significant differences between biological replicates, while analysis of similarities (ANOSIM) allowed us to test for differences between samples. We visualized the results using nonmetric multidimensional scaling (NMDS) (Primer-E). We performed all calculations using complete abundance matrices, as well as resampled matrices in which the number of sequenced reads per sample was made equal through random resampling: 1219 sequences per sample for Bacteria (3218 with replicates pooled), 1005 for Archaea (2502 with replicates pooled), and 2370 for $E u-$ karya (4911 with replicates pooled). We only showed resampled data results where resampling deviated from the full dataset result.

\section{Unimodal multivariate analysis}

We employed CANOCO 4.5 (Microcomputer Power) (ter Braak \& Šmilauer 2002) to relate our 
OTUs to environmental properties. Environmental data were transformed using $\ln (x+0.1)$, and temperature was adjusted to remove negative values by adding $1^{\circ} \mathrm{C}$ to each value. Preliminary detrended correspondence analysis yielded gradients close to 3 , so we chose to continue our analyses using the canonical correspondance analysis (CCA) unimodal approach. We employed the automatic forward selection feature in CANOCO to ensure selection of parameters that have low cross-correlation and explain the most variance. The significance of the first CCA axis and all CCA axes combined was tested using Monte Carlo permutation tests with 499 permutations (ter Braak \& Šmilauer 2002).

\section{Network analysis and data visualizations}

We examined co-occurrence patterns across domains using network analysis and significant linear Pearson correlations. For the input matrices we removed all singleton OTUs and only considered OTUs that occurred in at least $50 \%$ of the samples. We used Cytoscape (Shannon et al. 2003) to visualize the resulting data and only considered significant correlations with an R-value $>0.9$. We generated bacterial taxonomic bar graphs using Global Alignment Sequence Taxonomy (GAST) (Huse et al. 2008) and used Qiime v1.4.0 (Caporaso et al. 2010) to graphically display the output. The $\mathrm{R}$ package routines gplots and heatmap.2 were used to generate the heatmap summary of all microbial eukaryotic OTUs that were encountered with a frequency of $>1 \%$ at a given site (R Development Core Team 2008). All of our sequence data are MIMARKS compliant (Yilmaz et al. 2011) (Table S1 in Supplement 2 at www.intres.com/articles/suppl/a073p107_supp/) and have been deposited in the National Center for Biotechnology Information Sequence Read Archives under the Accession Number SRP041427. Bacterial V6 data were previously deposited under SRP016030, while eukaryotic V9 were previously deposited under SRP000903. Associated metadata can be found in Table S1.

\section{RESULTS}

\section{Sampling site characteristics}

The waters in the WAP were consistently cold $\left(<1^{\circ} \mathrm{C}\right)$ and experienced dramatic fluctuations in day length and sea ice cover during the study period. In the austral summer, deep samples (100 m) were more saline and had higher nutrient concentrations $\left(\mathrm{PO}_{4}, \mathrm{NO}_{3}, \mathrm{TN}, \mathrm{SiO}_{4}\right)$, while surface samples $(10 \mathrm{~m})$ contained higher phytoplankton biomass (chl $a_{\text {; }}$ Table 1). Within surface samples, we observed differences between inshore and offshore sites, with greater bacterial production (leucine incorporation) and organic substrates (POC and PN) at inshore sites (Table S1 in Supplement 2). In general there were no

Table 1. Contextual data for sites sampled. Differences between depths, inshore and offshore, and north and south comparisons between samples were assessed using Student's t-tests. PON: particulate organic nitrogen; DOC: dissolved organic carbon; POC: particulate organic carbon; ND: not determined. ${ }^{*} \mathrm{p}<0.1,{ }^{* *} \mathrm{p}<0.05,{ }^{* * *} \mathrm{p}<0.01$; no asterisk: not significant

\begin{tabular}{|c|c|c|c|c|c|c|}
\hline Variable & $\begin{array}{c}10 \mathrm{~m} \text { overall } \\
\text { avg. }\end{array}$ & $\begin{array}{c}100 \text { m overall } \\
\text { avg. }\end{array}$ & $\begin{array}{c}10 \mathrm{~m} \text { inshore } \\
\text { avg. }\end{array}$ & $\begin{array}{c}10 \text { m offshore } \\
\text { avg. }\end{array}$ & $\begin{array}{c}10 \text { m north } \\
\text { avg. }\end{array}$ & $\begin{array}{l}10 \text { m south } \\
\text { avg. }\end{array}$ \\
\hline Density & $27.2^{* *}$ & $27.4^{* *}$ & 27.2 & 27.2 & $27.2^{* *}$ & $27.1^{* *}$ \\
\hline Salinity & $33.8^{* *}$ & $34.2^{* *}$ & 33.8 & 33.9 & 33.8 & 33.8 \\
\hline Oxygen $\left(\mu \mathrm{mol} \mathrm{l^{-1 } )}\right.$ & $357^{*}$ & $276^{*}$ & 366 & 348 & 362 & 352 \\
\hline Temperature $\left({ }^{\circ} \mathrm{C}\right)$ & 0.756 & -0.224 & 0.773 & 0.739 & 0.765 & 0.747 \\
\hline $\mathrm{NO}_{3}\left(\mu \mathrm{mol} \mathrm{l} \mathrm{l}^{-1}\right)$ & $18.6^{*}$ & $24.8^{*}$ & $16.5^{*}$ & $20.8^{*}$ & 19.5 & 17.8 \\
\hline $\mathrm{NO}_{2}\left(\mu \mathrm{mol} \mathrm{l} \mathrm{l}^{-1}\right)$ & 0.38 & 0.28 & 0.25 & 0.50 & 0.35 & 0.40 \\
\hline PON $\left(\mu m o l ~ l^{-1}\right)$ & 47.6 & ND & 79.9 & 15.2 & 69.2 & 25.9 \\
\hline Total N $\left(\mu \mathrm{mol} \mathrm{l} \mathrm{l}^{-1}\right)$ & $28.3^{* *}$ & $36.3^{* *}$ & $25.1^{*}$ & $31.4^{*}$ & 29.4 & 27.2 \\
\hline $\mathrm{PO}_{4}\left(\mu \mathrm{mol} \mathrm{l} \mathrm{l}^{-1}\right)$ & $1.58^{* * *}$ & $2.10^{* * *}$ & $1.50^{*}$ & $1.65^{*}$ & 1.60 & 1.55 \\
\hline $\mathrm{Si}\left(\mu \mathrm{mol} \mathrm{l} \mathrm{l}^{-1}\right)$ & 53.2 & 68.6 & $70.8^{* *}$ & $35.5^{* *}$ & 53.2 & 53.2 \\
\hline $\operatorname{DOC}\left(\mu \mathrm{mol} \mathrm{l} \mathrm{l}^{-1}\right)$ & 45.7 & 43.4 & 46.4 & 45.0 & 46.5 & 45.7 \\
\hline POC $\left(\mu \mathrm{mol} \mathrm{l} \mathrm{l}^{-1}\right)$ & 210 & ND & 349 & 71.8 & 306 & 115 \\
\hline Chlorophyll a $\left(\mu g \mathrm{l}^{-1}\right)$ & 1.71 & 0.147 & $3.21^{*}$ & $0.215^{*}$ & 2.13 & 1.30 \\
\hline Fluorescence $\left(\mathrm{mg} \mathrm{m}^{-3}\right)$ & 2.30 & 0.189 & 4.10 & 0.506 & 3.14 & 1.47 \\
\hline Bacterial density $\left(\times 10^{6} \mathrm{ml}^{-1}\right)$ & 0.227 & 0.225 & 0.242 & 0.212 & $0.189^{*}$ & $0.266^{*}$ \\
\hline Leucine incorporation $\left(\mathrm{pmol} \mathrm{l}^{-1}\right.$ ) & 14.6 & ND & 22.9 & 6.37 & 18.8 & 10.5 \\
\hline
\end{tabular}


significant environmental differences between the corresponding northern and southern sampling stations (Table 1).

\section{Microbial community structure}

Our 3-domain assessment of the microbial communities of the WAP pelagic ecosystem generated $>150000$ bacterial, >50000 archaeal, and >60000 eukaryotic rRNA amplicon reads from our Palmer LTER study region along the WAP. We selected these sites in order to examine how microbial communities vary with depth, distance from shore, and latitudinal differences in sea ice cover.

Bacterial community composition varied significantly by depth (ANOSIM, $\mathrm{p}=0.007$ full, $\mathrm{p}=0.004$ resampled) and slightly among surface samples between inshore and offshore samples (ANOSIM, $\mathrm{p}=$ 0.08 full, $p=0.06$ resampled), but showed no significant north-south differences in community structure. NMDS and hierarchical clustering revealed that the inshore surface communities fell into 2 groups with $60 \%$ similarity, 1 composed solely of inshore surface samples and 1 containing all other samples including offshore surface, winter surface, and all deep samples, also sharing $60 \%$ similarity (Fig. 2). All bacterial samples taken together were $40 \%$ similar to each other. The winter surface sample was more similar to summer deep samples than to any summer surface sample from the same station (Fig. S1 in Supplement 1 at www.int-res. com/articles/suppl/a073p107_supp/). SIMPER analysis showed that 7 OTUs, identified as 'Candidatus Pelagibacter', Oceanospirallales, Balneatrix, Flavobacteriaceae, SAR324, Roseobacter, and Phycisphaeraceae, accounted for $>33 \%$ of the variation between surface and deep communities. Eukaryotes had the greatest degree of variation among samples, with some samples having only $20 \%$ similarity. Eukaryotic community composition varied significantly with depth and distance from shore (ANOSIM, $p=0.001$ and 0.03 , respectively, for the full dataset; $p=0.001$ and 0.027 for the resampled dataset), but as with bacterial communities failed to exhibit large differences in beta diversity (between sample diversity) between the north and south stations. Individual eukaryotic OTUs were unable to explain $>0.5 \%$ of this variation (SIMPER). We detected little variation among archaeal communities (summer $100 \mathrm{~m}$ and winter surface) due, in part, to our inability to detect archaea in surface summer samples, and there were few differences in the structure of corre-
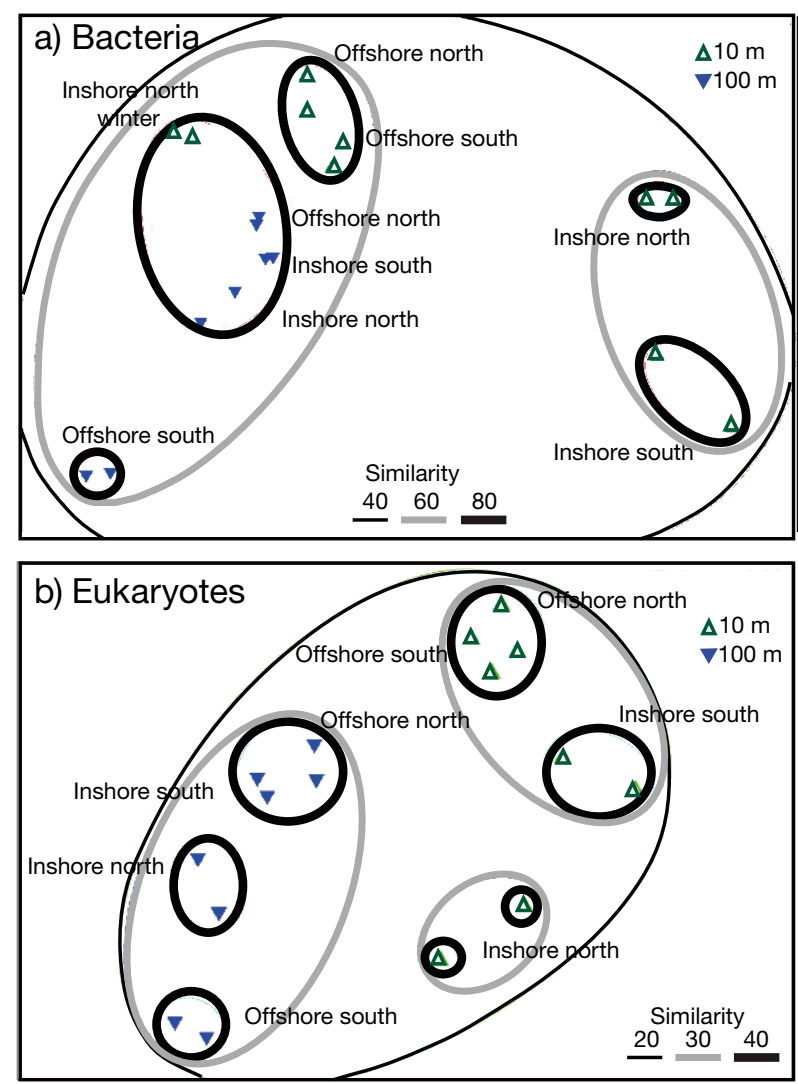

Fig. 2. Nonmetric multidimensional scaling of (a) bacterial Morisita-Horn and (b) eukaryotic Jaccard similarity matrices. Bacterial ordination based on samples collected in January and August 2008. Eukaryotic (minus metazoan operational taxonomic units [OTUs]) ordination based on samples collected during January 2008 only

sponding northern and southern communities (e.g. northern vs. southern inshore samples) (Fig. 3). We did observe significantly higher eukaryotic alpha diversity (species richness) at the northern inshore site (Fig. 4) and differences in the relative recoveries of individual eukaryotic OTUs (Fig. S2 in Supplement 1 at www.int-res.com/articles/suppl/a073p107 _supp/).

We conducted further analyses to identify the linkages between community composition and the supporting environmental and biological data. We were especially interested in co-occurrence patterns between bacteria and photosynthetic eukaryotes. CCA biplots summarize the relationship between environmental variables and bacteria (Fig. 5a) and eukaryotes (Fig. 5b). The underlying environmental variables determining community structure differed between bacterial and eukaryotic domains. For bacteria, CCA Axis 1 was most closely correlated with salinity, while CCA Axis 2 was most closely corre- 
Fig. 3. Archaeal 2-way cluster analysis. Samples were collected from $100 \mathrm{~m}$ depth in January 2008 and from the surface in August 2008 (winter). Abbreviations are as follows-MG1: Marine Group I Crenarchaeota; MG2: Marine Group II Euryarchaeaota; MG3: Marine Group III Euryarchaeota; remaining are miscellaneous Euryarchaeota groups. The matrix coding denotes the relative abundance with the matrix for a given OTU. A and B are sample replicates

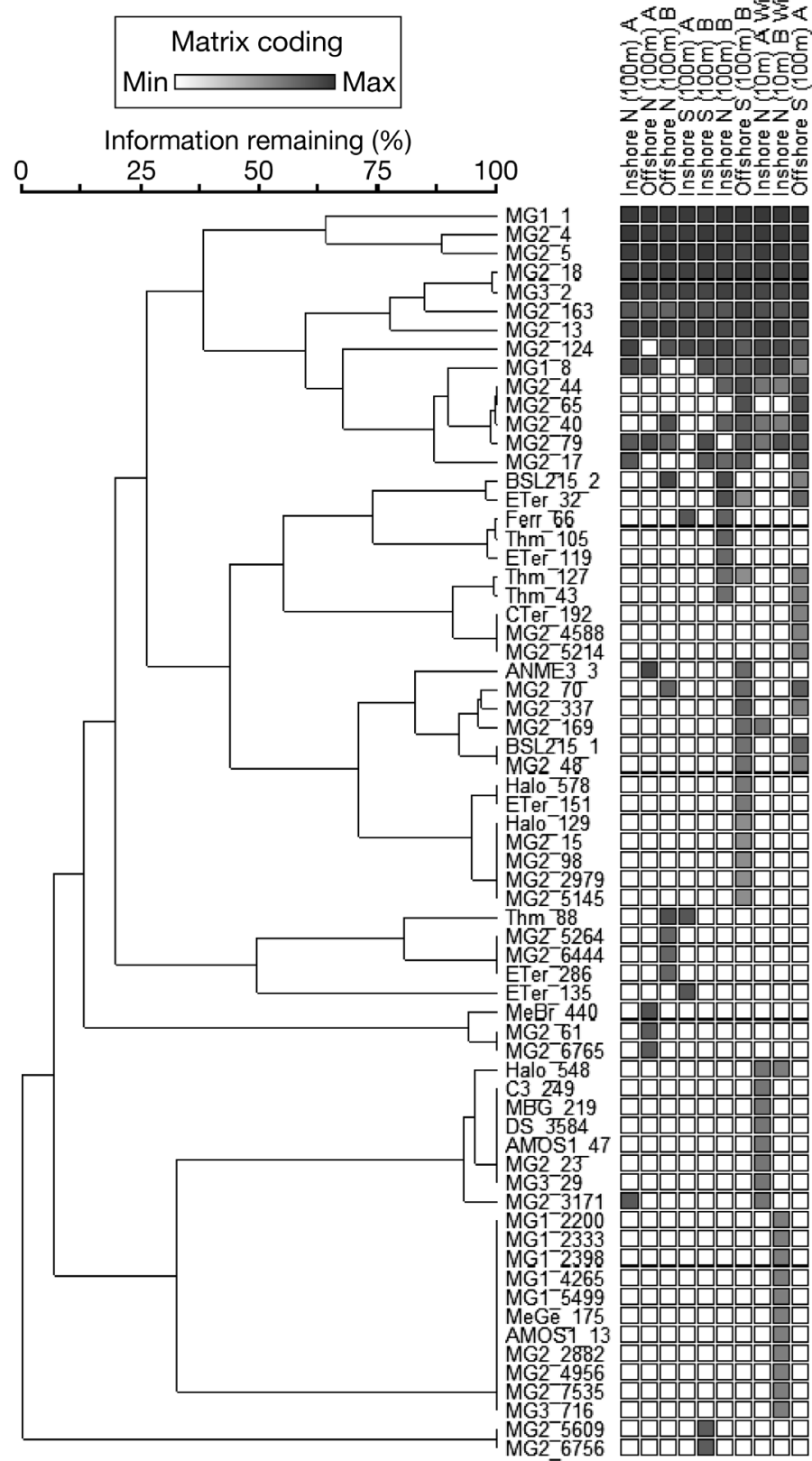

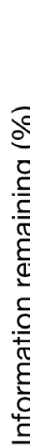

을

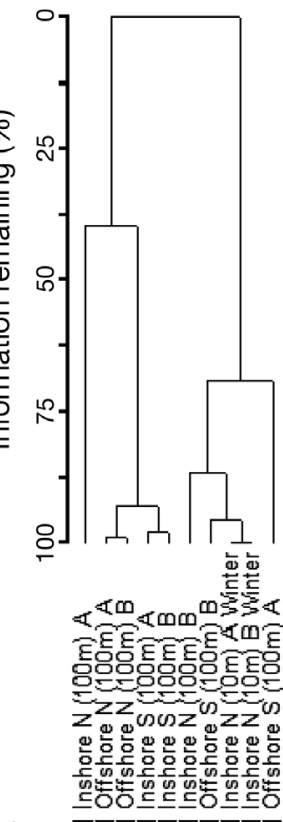

lated with silicate. The first CCA axis explained $33.6 \%$ of the variance in the dataset, and the first 2 axes combined explained $51.5 \%$ (Table S2 in Supplement 1 at www.int-res.com/articles/ suppl/a073p107_supp/). In addition to salinity and silicate, depth and phosphate were also significant explanatory variables shaping bacterial community structure. More so than NMDS, the bacterial CCA analysis showed a marked separation between shallow and deep samples along the vertical salinity gradient. As with NMDS no obvious north-south separation between samples was evident in our biplots.

Eukaryotic CCA analysis showed a less marked difference between community structures at $100 \mathrm{~m}$ than for bacterial communities. The first CCA axis was defined by oxygen, and the second, by temperature, and explained $22.3 \%$ (Axis 1) and 39.3\% (Axes 1 \& 2) of the variation in the dataset, respectively (Table S2). The offshore south $100 \mathrm{~m}$ sample in particular was most positively correlated with higher temperature as was seen in the bacterial community analyses.

Due to the limited number of archaeal samples relative to environmental parameters available, we chose to conduct a 2 -way cluster analysis to explore the relationship between samples and OTU groups (Fig. 3) instead of conducting a CCA. The resulting 2-way cluster diagram shows shared OTU groupings among different samples. Unlike bacterial assemblages, winter inshore $10 \mathrm{~m}$ archaeal assemblages clustered most closely with offshore summer southern communities. As with both bacterial and eukaryotic samples, no northsouth contrast was revealed in our archaeal analyses.

Network analyses using significant Pearson correlations identified positive inter-domain (bacterial-eukaryotic) associations between, for example, photosynthetic and heterotrophic community (Fig. 6a,b) members such as diatoms and Rhodobacteraceae and Cryomorphaceae members (Fig. 6a), as well as diatomSAR11 associations. Our network analyses also revealed intra-domain (eukaryoticeukaryotic) correlations, possibly symbiotic or parasitic affiliations (Radiolarian-like-protist and dinoflagellate [alveolate] associations), or perhaps just co-occurring protistan taxa shaped by common environmental constraints. 


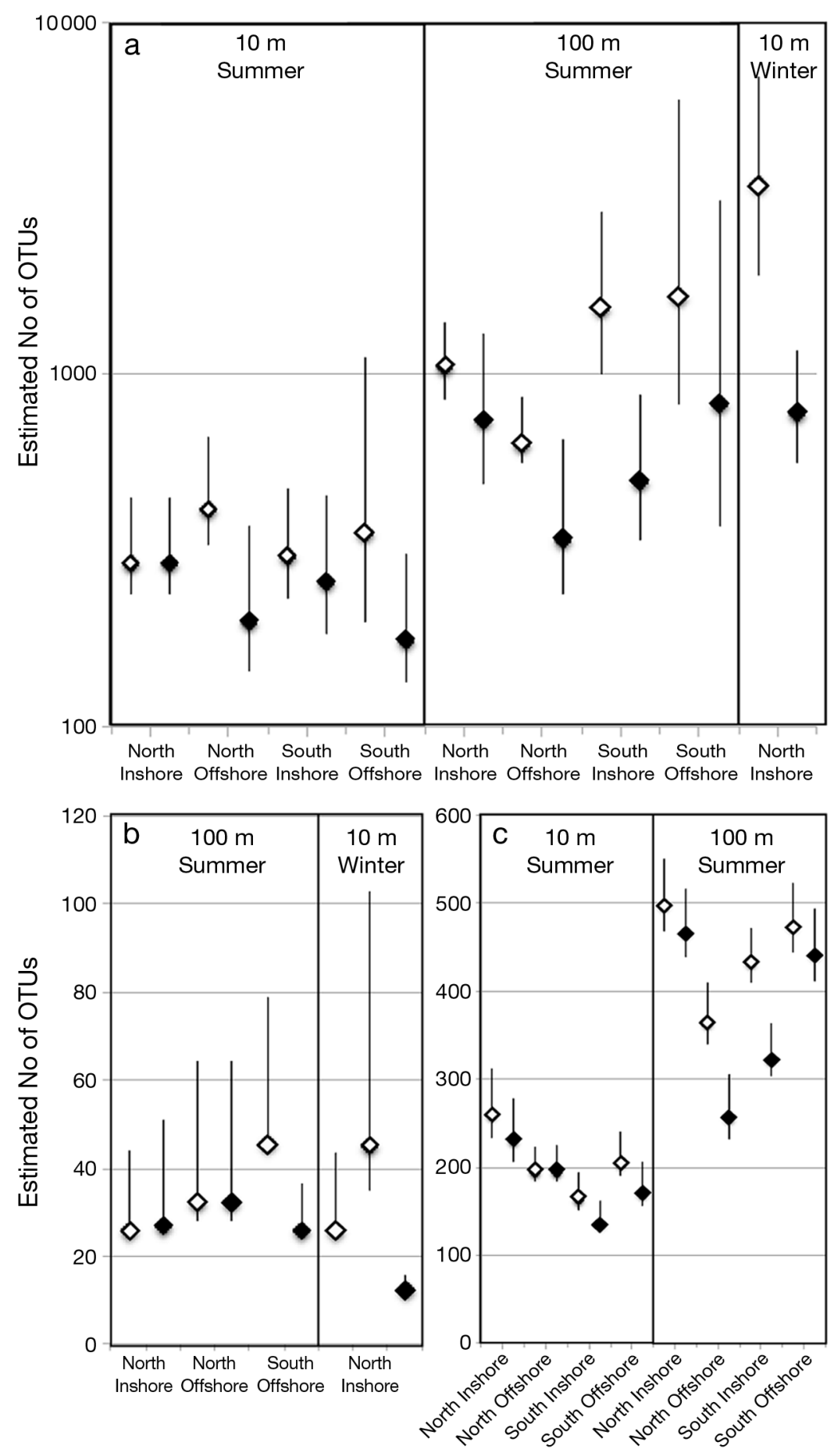

Fig. 4. Species richness estimates of (a) bacterial, (b) archaeal, and (c) eukaryotic OTUs with Bonferroni-corrected 95\% confidence intervals for all samples across a given domain. Filled diamonds are for resampled data. For each of the bacterial samples 2 replicates were pooled. Eukaryotic diversity estimation required the 2 replicate samples to calculate a single incidence-based richness estimate for a given pair of samples. For archaeal estimates, south offshore $100 \mathrm{~m}$ and winter north inshore replicates are shown individually, north and south offshore $100 \mathrm{~m}$ replicates were pooled, and south inshore $100 \mathrm{~m}$ estimates were not done. Bacterial and archaeal estimates were calculated using CatchAll, while eukaryotic estimates were calculated using Chao2 as implemented in SPADE

\section{Richness and community composition}

We detected the highest richness within the bacterial domain (Table 2, Fig. 4a). We observed 234 bacterial OTUs, on average, with an estimated richness of 520. As with community composition, bacterial richness varied by depth, with $100 \mathrm{~m}$ samples having greater observed and estimated diversity (Table 2, Fig. 4a). The winter sample had almost twice the estimated richness (2125) of any summer sample. Over half ( $51 \%$ ) of sequences were classified to the genus level, while an additional $32 \%$ of sequences were identified to the family level. The majority $(75 \pm 2 \%$ [SE]) of sequences were identified as Proteobacteria, primarily in the Alpha- (36 $\pm 3 \%)$ and Gamma- (33 $\pm 2 \%$ ) classes (Fig. S1 in Supplement 1). Alphaproteobacteria, especially Rhodobacterales, were more important in surface samples, accounting for $43 \pm 2 \%$ of sequences compared to 30 $\pm 4 \%$ at $100 \mathrm{~m}$. Inshore surface samples were distinguished by a high prevalence of Roseobacter (15\% in the north and 6\% in the south). 'Candidatus Pelagibacter' (SAR11) was more consistent across surface samples, accounting for $23 \pm 2 \%$ of all sequences. Gammaproteobacteria, primarily SAR86, SAR92, Oceanospirillales, Balneatrix, and a number of unclassified OTUs, had greater relative abundance in deep samples, accounting for 36 $\pm 1 \%$ of sequences. Deltaproteobacteria, especially Desulfobacterales, Nitrospinaceae, and SAR324, were more common at $100 \mathrm{~m}$ depth, accounting for $7 \pm 3 \%$ of sequences in deep samples but $<1 \%$ in surface samples. The bulk of the remaining sequences consisted of Flavobacteria, Planctomycetes, and Deferribacteres. Flavobacteria were most abundant in the northern inshore site $(28 \%)$. Planctomycetes, especially Zarvarzinella, were common at both northern and southern inshore sites $(8 \pm 1 \%)$. Deferribacteres were mostly found at $100 \mathrm{~m}$ depth $(7 \pm 3 \%)$.

Eukaryotic rRNA gene V9 hypervariable-region sequencing yielded an overall average of 260 observed and 300 esti- 

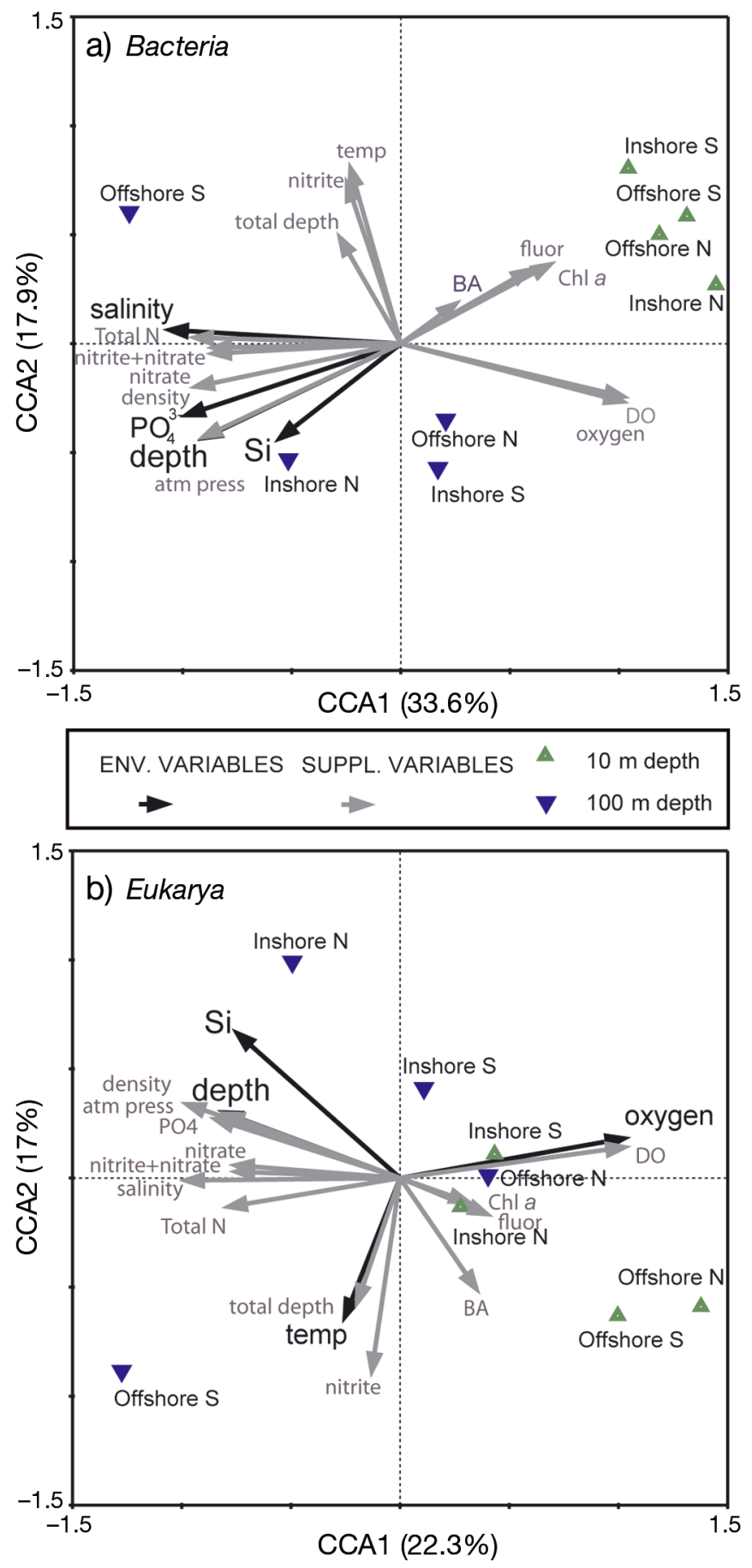

Fig. 5. Canonical correspondence analysis (CCA) based on (a) bacterial and (b) eukaryotic OTU libraries from water samples collected in January 2008. Explanatory environmental variables (black arrows) and supplementary environmental variables (grey arrows) are shown

mated OTUs. We did not sequence eukaryotic winter samples so we are unable to contrast seasonal richness patterns in eukaryotes; however, we can say that overall, deeper samples were significantly richer than surface samples. More importantly, we detected increased eukaryotic richness in surface $(10 \mathrm{~m})$ and deep $(100 \mathrm{~m})$ inshore northern stations as compared to southern ones, but offshore northern and southern stations revealed either no difference or increased richness at depth in the south. Surprisingly, dinoflagellate-related OTUs that constituted the largest eukaryotic OTU class type in our dataset (Fig. S2 in Supplement 1) did not show depth patterns that were consistent with our expectation that photoautotrophs dominate the euphotic zone, and heterotrophs, deeper waters, nor did pigment data derived by high-performance liquid chromatography suggest that a disproportionate fraction of the phototrophic community was composed of dinoflagellates. Cryptophytes and diatoms, also among the numerically dominant phototrophs, did not show surface or depth contrasts that might be anticipated of strict phototrophy. This is in contrast to groups like haptophytes which showed increased amplicon read numbers at $10 \mathrm{~m}$ versus $100 \mathrm{~m}$ depths. Within $10 \mathrm{~m}$ samples, we observed greater relative abundances of cryptophytes at inshore sites, while offshore sites were dominated by dinoflagellates and diatoms (Fig. S2 in Supplement 1). Archaea had the lowest richness of the 3 domains, with an average of 22 observed and 33 estimated OTUs (Table 2). Marine Group I Crenarchaeota (MG1: Thaumarchaeota) and Marine Groups II and III (MG2, MG3: Euryarchaeota) dominated our samples accompanied by a number of less abundant Thermoplasmatales, Halobacteriales, and Methanosarcinales. MG3 was significantly more abundant $(\mathrm{p}<0.05)$ in our summer northern inshore and southern offshore samples $(8 \%$ relative abundance vs. $0.5 \%$ for all other samples). The winter assemblage differed from summer assemblages with a higher abundance of Thaumarchaeota $(80 \%)$ and a lower abundance of MG2 (19\%).

\section{DISCUSSION}

\section{Seasonal, vertical and spatial variation in phytoplankton-heterotroph coupling}

We observed significant differences in microbial community structure (and apparent differences in archaeal abundance) based on depth (10 and $100 \mathrm{~m})$ (bacteria and eukaryotes), proximity to shore (eukaryotes) and between winter and summer seasons (bacteria and archaea). Depth-based differences were consistent with previous reports of strong vertical stratification in community composition (DeLong 
a

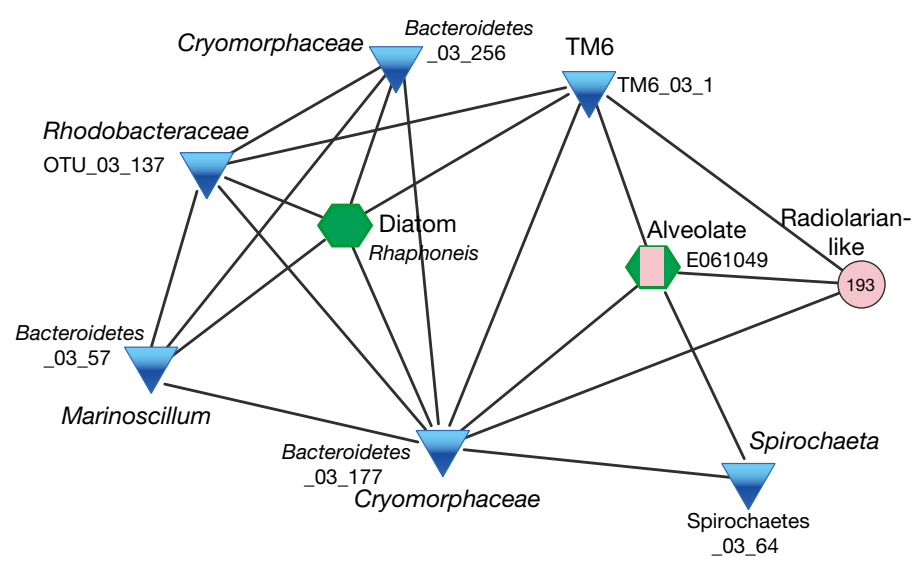

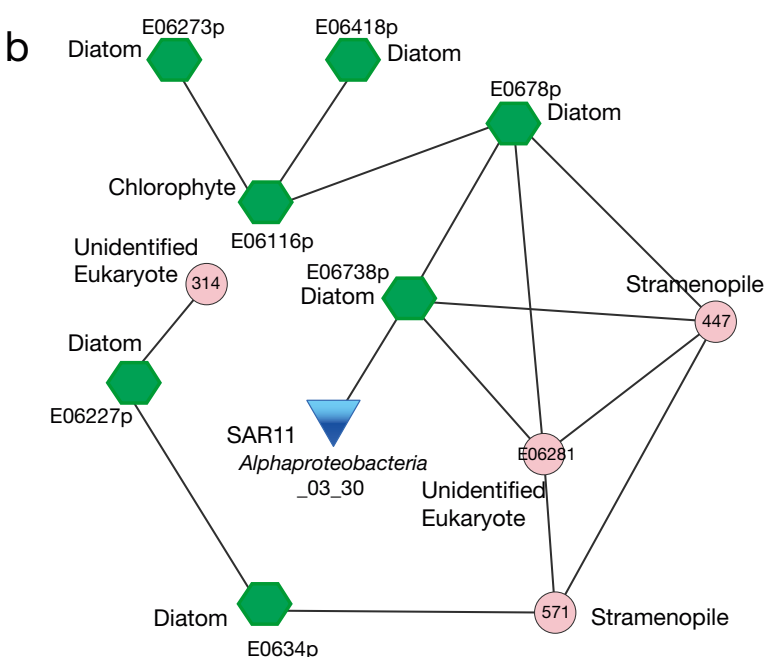

Fig. 6. Network analysis of combined bacterial and eukaryotic matrices. Bacteria are indicated by triangles. Pink circles represent microbial eukaryotes that are most likely heterotrophic. Green hexagons represent phototrophs. The pink and green hexagon represents an alveolate of unknown trophic status. (a) A network highlighting alveolate-radiolarian interactions and

(b) a network focusing on interactions between SAR11 and an unknown diatom. OTU designations are shown

Table 2. Observed and estimated richness for Palmer Station LTER samples using $97 \%$ similarity values for Bacteria and Archaea and $94 \%$ similarity values for Eukarya. Replicate samples for Bacteria and Archaea were pooled unless indicated with a replicate designation after the sample number (e.g. 9.1). For eukaryotic alpha diversity estimation, replicates were treated independently as is done for Chao2 estimation. For eukaryotes metazoan reads were removed. OTU: operational taxonomic units; dashes: data not available

\begin{tabular}{|c|c|c|c|c|c|c|c|c|c|c|c|c|}
\hline \multirow[b]{2}{*}{ ID } & \multirow[b]{2}{*}{ Location } & \multirow[b]{2}{*}{$\begin{array}{l}\text { Depth } \\
\text { (m) }\end{array}$} & \multirow[b]{2}{*}{ Month } & \multicolumn{3}{|c|}{ Archaea } & \multicolumn{3}{|c|}{ Bacteria } & \multicolumn{3}{|c|}{ Eukarya } \\
\hline & & & & $\begin{array}{l}\text { No. of } \\
\text { reads }\end{array}$ & $\begin{array}{l}\text { Obs. } \\
\text { OTUs }\end{array}$ & $\begin{array}{l}\text { Est. } \\
\text { OTUs }\end{array}$ & $\begin{array}{l}\text { No. of } \\
\text { reads }\end{array}$ & $\begin{array}{l}\text { Obs. } \\
\text { OTUs }\end{array}$ & $\begin{array}{l}\text { Est. } \\
\text { OTUs }\end{array}$ & $\begin{array}{l}\text { No. of } \\
\text { reads }\end{array}$ & $\begin{array}{l}\text { Obs. } \\
\text { OTUs }\end{array}$ & $\begin{array}{l}\text { Est. } \\
\text { OTUs }\end{array}$ \\
\hline 1 & Inshore, & 10 & Jan & - & - & - & 3218 & 126 & 289.4 & 6369 & 211 & 259 \\
\hline $1^{\mathrm{a}}$ & north & 10 & Jan & - & - & - & 3218 & 126 & 289.4 & 4911 & 188 & 229.3 \\
\hline 2 & Inshore, & 100 & Jan & 4295 & 21 & 25.7 & 11454 & 513 & 1050.4 & 5568 & 430 & 498 \\
\hline $2^{\mathrm{a}}$ & north & 100 & Jan & 2502 & 20 & 27 & 3218 & 303 & 735.4 & 4911 & 405 & 466.7 \\
\hline 3 & Offshore, & 10 & Jan & - & - & - & 17676 & 195 & 415 & 4911 & 177 & 194.1 \\
\hline $3^{\mathrm{a}}$ & north & 10 & Jan & - & - & - & 3218 & 103 & 198.8 & 4911 & 176 & 194.5 \\
\hline 4 & Offshore, & 100 & Jan & 2502 & 21 & 32.3 & 29555 & 350 & 630.3 & 11775 & 313 & 363.5 \\
\hline $4^{\mathrm{a}}$ & north & 100 & Jan & 2502 & 21 & 32.3 & 3218 & 155 & 340.9 & 4911 & 211 & 255.2 \\
\hline 5 & Offshore, & 10 & Jan & - & - & - & 11845 & 143 & 353.5 & 9078 & 180 & 204.9 \\
\hline $5^{\mathrm{a}}$ & south & 10 & Jan & - & - & - & 3218 & 93 & 176.7 & 4911 & 147 & 169.9 \\
\hline 6 & Offshore, & 100 & Jan & 9724 & 34 & 45.4 & 21306 & 585 & 1678.4 & 5996 & 407 & 472.6 \\
\hline $6^{\mathrm{a}}$ & south & 100 & Jan & 2502 & 24 & 25.9 & 3218 & 260 & 819.4 & 4911 & 375 & 440.8 \\
\hline 7 & Inshore, & 10 & Jan & - & - & - & 4869 & 146 & 303.4 & 7623 & 145 & 162.8 \\
\hline $7^{a}$ & south & 10 & Jan & - & - & - & 3218 & 120 & 256.8 & 4911 & 125 & 136.4 \\
\hline 8 & Inshore, & 100 & Jan & - & - & - & 37524 & 546 & 1551.5 & 11500 & 387 & 431.4 \\
\hline $8^{a}$ & south & 100 & Jan & - & - & - & 3218 & 206 & 493.9 & 4911 & 285 & 323.3 \\
\hline 9.1 & Inshore, & 10 & July & 11941 & 21 & 25.9 & - & - & - & - & - & - \\
\hline 9.2 & north & 10 & July & 16026 & 24 & 45.3 & - & - & - & - & - & - \\
\hline 9 & Inshore, & 10 & July & - & - & - & 18410 & 645 & 3474.8 & - & - & - \\
\hline $9^{\mathrm{a}}$ & north & 10 & July & 2502 & 12 & 12.2 & 3218 & 273 & 775.2 & - & - & - \\
\hline
\end{tabular}

et al. 2006, Brown et al. 2009) reported from other environments. Results from CCA showed that community composition correlated with salinity and silicate for bacteria and temperature and oxygen for eukary- otes: all factors that are influenced by water column vertical stratification. In this context, the similarity between our $10 \mathrm{~m}$ surface winter sample and our $100 \mathrm{~m}$ summer samples is not surprising. This similar- 
ity reflects the origin of the summertime, minimally modified remnant 'Winter Water' below the seasonal thermocline (Martinson et al. 2008, Ducklow et al. 2012b). During the Antarctic winter, the water column is divided into 2 main water masses: warm, nutrient-rich Circumpolar Deep Water (CDW) overlaid by cold, fresh Antarctic Surface Water (AASW) (Clarke et al. 2007, Martinson et al. 2008). The AASW results from convective mixing and cooling in winter and can extend to several hundred meters in depth. In the spring, increasing surface temperatures and meltwater from sea ice and glaciers result in water column stratification and the isolation of a deep remnant of the cold, saline AASW. This cold remnant, with a core at about $100 \mathrm{~m}$, is traditionally known as Winter Water (WW) (Mosby 1934). Previous findings suggested that WW $100 \mathrm{~m}$ communities in summer and winter surface microbial communities might share some features, including more abundant archaea (Massana et al. 1998, Church et al. 2003). Furthermore, in a comparison of clone libraries generated from winter and summer surface water samples, Grzymski et al. (2012) found increased abundance of genes related to chemolithoautotrophy, typically found in deeper marine habitats, during the Antarctic winter. Our results demonstrate that seasonal patterns in WAP water column structure are reflected in bacterial and archaeal community composition.

Several lines of evidence suggest that the mechanism driving the observed succession of microbial community structure from winter to summer is enrichment by organic matter generated by photoautotrophs. Order of magnitude increases in bacterial production rates (Ducklow et al. 2012b) must be accompanied by increased resources. The summer bacterial community is characterized by many sequences indicating heterotrophic capabilities (Grzymski et al. 2012). Microautoradiography-FISH (fluorescence in situ hybridization) determinations showed that the most abundant OTUs utilized amino acids and dissolved protein (Straza et al. 2010). A summer bacterial community from the WAP demonstrated reduced diversity in response to experimental glucose enrichment, consistent with our field observations (Ducklow et al. 2011). In contrast, a summertime sample from the Mediterranean Sea grown over 5 generations ( $15 \mathrm{~d}$ ) in continuous culture in the presence of a complex substrate derived from a phytoplankton culture exhibited increased diversity relative to an unamended control (Landa et al. 2013). The samples and experimental conditions differed between these experiments, preventing simple conclu- sions about relationships between organic enrichment and diversity.

In the present study, we did not find a significant correlation between phytoplankton biomass and bacterial community composition within summer $10 \mathrm{~m}$ samples, although CCA analyses showed silicate to be a significant factor influencing bacterial community structure. The LTER study grid encompasses an inshore-offshore gradient, with average (1993 to 2013) phytoplankton biomass ranging from

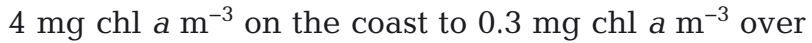
the continental slope (http://pal.lternet.edu/data; Smith et al. 1996, 1998a,b, Garibotti et al. 2005). We observed high phytoplankton biomass ( $\mathrm{chl} \mathrm{a}$ ) at the inshore stations in the present study. Despite marked differences in chlorophyll and eukaryotic community composition, unlike eukaryotic communities, bacterial community composition between inshore and offshore sites was only significantly different at the $90 \%$ but not at the $95 \%$ confidence level based on our ANOSIM analyses. While eukaryotic communities were much less similar to each other overall than bacterial communities, caution should be applied in interpreting absolute magnitudes of the similarity values between abundance-based data (bacteria) and presence/absence (eukaryotes) data. We suggest that none of the surface bacterial communities were carbon-limited in summer, but that the relative differences in phytoplankton biomass between sites may in some way influence bacterial community composition.

\section{Community composition across 3 domains}

Most studies of bacterial diversity in Antarctic waters have used culture-dependent or community fingerprinting techniques. For example, significant inter-seasonal variation in bacterial community composition was found using denaturing gradient gel electrophoresis (Murray et al. 1998, Murray \& Grzymski 2007). A few studies have used clone libraries to investigate bacterial diversity, finding high diversity within the Gammaproteobacteria and Cytophaga-Flavobacteria-Bacteroidetes (CFB) divisions (Gentile et al. 2006, Piquet et al. 2011). More recently, studies have adopted next-generation sequencing approaches to contrast sub-Antarctic and Antarctic bacterial community richness, structure, and biogeography (Ghiglione \& Murray 2012, Wilkins et al. 2013a,b).

Alphaproteobacteria, Gammaproteobacteria, and Bacteroidetes dominated the bacterial communities 
we sampled (cf. Gentile et al. 2006, Pommier et al. 2007, Piquet et al. 2011, Ghiglione \& Murray 2012, Wilkins et al. 2013a,b). We identified abundant amplicons from several 'ubiquitous' clusters such as SAR11, SAR86, SAR324 (Pommier et al. 2005), but also noted the absence of cyanobacteria such as Prochlorococcus and Synechococcus that are typically absent or rare in bacterial communities in the Antarctic Zone (Wilkins et al. 2013a,c). In addition to the ubiquitous and dominant SAR11, Roseobacter was another significant alphaproteobacterium in our study, where it was likely associating with phytoplankton at shallow depths (Ghiglione \& Murray 2012, Wilkins et al. 2013a,c).

Despite a growing body of knowledge, linking microbial community composition to function remains a significant challenge. However, the contrasts we observed among the abundances of different taxa are suggestive of coupling between primary productivity and bacterial/archaeal presence and community composition. Although overall community composition did not vary significantly among surface samples, a few clades displayed marked differences in relative abundance between sites, indicating different ecological niches at different sampling locations. For example, Planctomycetes, especially Zarvarzinella, were more abundant at near-shore sites where algal biomass was highest. This lies in contrast to other studies wherein Planctomycetes were detected in low abundance in the Southern Ocean (Wilkins et al. 2013c). Culture-dependent and -independent techniques have shown that the CFB division is particularly prominent in situations with high DOC availability, e.g. in sea ice (Brinkmeyer et al. 2003) or during phytoplankton blooms (Glöckner et al. 1999, Abell \& Bowman 2005), perhaps due to superior competitive exploitation of algal-derived carbon (Pizzetti et al. 2011). Positive associations between diatoms and Rhodobacteraceae, Cryomorphaceae, and SAR11, respectively, in our study also suggest coupling between heterotrophs and photoautotrophs. The significantly increased relative abundance of some proteobacterial clusters (e.g. Desulfobacterales, Nitrospinaceae, SAR324) in our $100 \mathrm{~m}$ samples could indicate that chemolithotrophy is relatively more important deeper in the water column (Grzymski et al. 2012) in the summer. This is consistent with Ghiglione \& Murray's (2012) detection of Desulfobacterales in winter samples in the Antarctic Peninsula and Swan et al.'s (2011) inference of SAR324's role in chemautotrophy in the cold, dark ocean. Similarly, archaeal abundance was apparently very low in summer surface waters.
These bacterial and archaeal distribution patterns may reflect an inability of chemolithotrophs to compete successfully under summer conditions.

A notable aspect of our study was our use of amplicon pyrosequencing to assess the diversity of all 3 microbial domains, including eukaryotes. Our study detected similar magnitude and trends in increased bacterial richness in winter versus summer as reported previously (Ghiglione \& Murray 2012), but also added insights into archaeal and eukaryotic richness with depth and location relative to the shoreline. Namely, archaea showed opposite trends to bacteria, with decreased richness in our resampled datasets in the winter versus summer and with overall numbers of OTUs an order of magnitude less than those for bacteria and eukaryotes. Like bacteria, eukaryotes also displayed increased richness at depth, while archaeal richness at different depths was difficult to ascertain given our inability to detect archaea in summer surface samples.

Previous studies of WAP eukaryotic diversity have relied primarily on pigment data and microscopy (Rodríguez et al. 2002a,b, Garibotti et al. 2003a,b, Annett et al. 2010) or only considered richness (Amaral-Zettler et al. 2009). Large diatoms and cryptomonads generally account for the bulk of phytoplankton biomass, while unidentified photosynthetic flagellates are numerically dominant (Villafañe et al. 1993, Rodríguez et al. 2002a, Garibotti et al. 2003b, Annett et al. 2010). Garibotti et al. (2003b) observed strong inshore-to-offshore gradients in biomass and community composition and attributed differences between northern and southern inshore blooms (cryptomonads in the north versus diatoms in the south) to differential timing of sea ice retreat. Diatom assemblages are highly variable from year to year (Annett et al. 2010), although several genera including Corethron, Chaetoceros, Fragilariopsis, Odontella, and Nitzschia are common (Garibotti et al. 2003a, Annett et al. 2010), and often co-occur with Phaeocystis antarctica (Rodríguez et al. 2002a, Garibotti et al. 2003b). Cryptophytes were more prevalent in the northern surface waters, but dinoflagellates were the most abundant OTU in our study. The prevalence of dinoflagellates was not consistent with our pigment data or microscopic observations. One likely explanation for over-representation of dinoflagellate-related OTUs may be that dinoflagellates are known to possess many copies of their rRNA genes (>12000 for dinoflagellates such as Akashiwo sanguinea; Zhu et al. 2005), while picoeukaryotes may have 4 orders of magnitude fewer. Another more speculative explanation is that perhaps the dinofla- 
gellate signals detected in large quantities in our study are the result of these cells engaging in kleptoplasty (chloroplast theft from other phototrophs) (Gast et al. 2007) allowing them to serve as mixotrophs as needed. This may also help explain why we failed to see dinoflagellate-specific pigment signatures in our high performance liquid chromatography data. Another possible explanation is that the detected dinoflagellate signal is derived from heterotrophic and not phototrophic dinoflagellates. Results of our network analyses pointed to Group I alveolates known to include parasitic and therefore heterotrophic clades as possible contributors to eukaryotic niche diversity as a whole. Furthermore, diatom and cryptophyte abundance did not vary significantly with depth, suggesting possible alternative survival strategies such as mixotrophy or heterotrophy (Bavestrello et al. 2000, Tuchman et al. 2006) or possible persistence of environmental DNA (eDNA) (Charvet et al. 2012a,b).

\section{Microbial diversity, resilience, and climate change}

Comeau et al. (2011) conducted a similar, 3-domain pyrosequencing study in the Amundsen Gulf, Canadian Arctic, over the 2003 to 2010 period of rapid warming and sea ice loss. They observed significant changes in community composition within the bacterial, archaeal, and eukaryotic domains over time, and reductions in overall bacterial diversity when samples were pooled into pre- and post-2007 groups. The Palmer LTER study region encompasses a strong climatic gradient running roughly north to south along the Antarctic Peninsula (Martinson et al. 2008, Stammerjohn et al. 2008). Changes have been more dramatic in the northern part of the region, with greater atmospheric and ocean warming (Meredith \& King 2005) and larger reductions in sea ice cover. In response, the region has experienced reductions in the populations of ice-dependent species such as Adèlie penguins (Ducklow et al. 2012a), Antarctic krill (Atkinson et al. 2004), and large-celled phytoplankton (Montes-Hugo et al. 2009) over the past few decades. Thus, the WAP presents north and south regions at different stages of climate change, sea ice reduction, and ecosystem transformation. It is intriguing that despite well-documented latitudinal trends in phytoplankton and higher trophic levels, we only observed significant differences in microbial richness among eukaryotic microbes and not their bacterial and archaeal counterparts. These differences in eukaryotic richness were not consistent between inshore and offshore sites, so we assume that they are not merely the effect of diversity increases due to eDNA from surface waters. Betadiversity patterns between northern and southern stations were less obvious, except perhaps for northern inshore eukaryotic communities. These observations relate to ongoing questions about microbial biogeography and community resilience.

The similarity observed between northern and southern assemblages may reflect the timing of sampling. We found that the oceanographic conditions at our sampling sites were quite similar at this time (Table 1). Many WAP latitudinal trends (i.e. temperature and sea ice duration and extent) are most apparent during autumn, winter, and spring (Ducklow et al. 2012a). Properties such as sea ice extent or primary production may or may not reflect gradients or longer term trends in any single year.

Microbial communities can be similar at kilometer distances, but dissimilar 10 s to 100 s of kilometers apart, supporting the idea of coherent community patches in the open sea (Hewson et al. 2006, McCliment et al. 2012). Surface currents in the WAP are $\sim 0.1$ to $1 \mathrm{~m} \mathrm{~s}^{-1}$ (Savidge \& Amft 2009), giving an advective timescale between the northern and southern stations of 5 to $10 \mathrm{~d}$. Bacterial assemblages should have ample time for turnover during transit, so latitudinal similarity over this distance due simply to physical mixing is unlikely (Wilkins et al. 2013b).

Microbial community resilience may also contribute to the observed lack of variation between northern and southern sites overall. Microbial community composition can be sensitive to disturbances in temperature and carbon enrichment among other factors (Allison \& Martiny 2008). However, fast growth rates, metabolic flexibility, and rapid evolution could increase the stability of microbial community composition and facilitate return to a pre-disturbance state. Microbial communities might vary between the north and south during the winter and spring when greater environmental differences are observed, but then quickly reach a common summer community composition. In contrast, larger, longer lived organisms integrate the effects of change over years (krill) to decades (penguins, seals).

\section{CONCLUSIONS}

Analysis of microbial eukaryotic, bacterial, and archaeal communities from 4 sites separated by 200 (cross-shelf) and $400 \mathrm{~km}$ (alongshelf) along the WAP revealed relatively low spatial variability in microbial 
community composition. Community composition responded more to the environmental variability represented by 10 and $100 \mathrm{~m}$ depths than to more subtle differences in production and climate forcing between different sites. Northern versus southern patterns in richness were only represented in inshore microbial eukaryotic communities. Furthermore, we found that bacterial and archaeal assemblages in $100 \mathrm{~m}$ summer samples were similar to those in winter surface $(10 \mathrm{~m})$ communities, reflecting established seasonal patterns in water column stratification and turnover. While we can begin to speculate on relative differences in community function based on SSU rRNA gene amplicon sequencing, further efforts are needed to examine the abundance and expression of functional genes in order to find the connections between microbial communities and ecosystem function in this fragile and rapidly changing region.

Acknowledgements. Funding was provided by NSF DEB0717390 to L.A.Z. (MIRADA-LTERS) and NSF Awards OPP0217282 and 0823101 (Palmer LTER) from the Antarctic Organisms and Ecosystems Program to H.W.D. We thank our LTER colleagues, especially Kristen Myers and Matthew Erickson, US Antarctic Program scientific support staff from Raytheon Polar Services, and the officers and crew of ARSV 'LM GOULD' (Edison Chouest Offshore). We thank Elizabeth McCliment for help with pyrosequencing and Susan Huse for bioinformatics support.

\section{LITERATURE CITED}

Abell GCJ, Bowman JP (2005) Ecological and biogeographic relationships of class Flavobacteria in the Southern Ocean. FEMS Microbiol Ecol 51:265-277

> Agogué H, Lamy D, Neal PR, Sogin ML, Herndl GJ (2011) Water mass-specificity of bacterial communities in the North Atlantic revealed by massively parallel sequencing. Mol Ecol 20:258-274

Alber M, Reed D, McGlathery K (2013) Coastal long term ecological research introduction to the special issue. Oceanography (Wash DC) 26:14-17

Allison SD, Martiny JBH (2008) Resistance, resilience, and redundancy in microbial communities. Proc Natl Acad Sci USA 105:11512-11519

Amaral-Zettler LA, McCliment EA, Ducklow HW, Huse SM (2009) A method for studying protistan diversity using massively parallel sequencing of V9 hypervariable regions of small-subunit ribosomal RNA genes. PLoS ONE 4:e6372

Annett AL, Carson DS, Crosta X, Clarke A, Ganeshram RS (2010) Seasonal progression of diatom assemblages in surface waters of Ryder Bay, Antarctica. Polar Biol 33: $13-29$

Atkinson A, Siegel V, Pakhomov E, Rothery P (2004) Longterm decline in krill stock and increase in salps within the Southern Ocean. Nature 432:100-103

Azam F, Fenchel T, Field JG, Gray JS, Meyer-Reil LA,
Thingstad F (1983) The ecological role of water-column microbes in the sea. Mar Ecol Prog Ser 10:257-263

- Bavestrello G, Arillo A, Calcinai B, Cattaneo-Vietti R and others (2000) Parasitic diatoms inside Antarctic sponges. Biol Bull 198:29-33

Brinkmeyer R, Knittel K, Jurgens J, Weyland H, Amann R, Helmke E (2003) Diversity and structure of bacterial communities in Arctic vs. Antarctic pack ice. Appl Environ Microbiol 69:6610-6619

> Brown MV, Philip GK, Bunge JA, Smith MC and others (2009) Microbial community structure in the North Pacific Ocean. ISME J 3:1374-1386

Bunge JA (2011) Estimating the number of species with CatchAll. In: Proc Pacific Symp on Biocomputing p 121-130

Caporaso JG, Kuczynski J, Stombaugh J, Bittinger K and others (2010) QIIME allows analysis of high-throughput community sequencing data. Nat Methods 7:335-336

Chao A, Shen TJ (2010) SPADE (species prediction and diversity estimates), http://chao.stat.nthu.edu.tw/software CE.html

> Charvet S, Vincent WF, Comeau A, Lovejoy C (2012a) Pyrosequencing analysis of the protist communities in a High Arctic meromictic lake: DNA preservation and change. Front Microbiol 3:422

Charvet S, Vincent WF, Lovejoy C (2012b) Chrysophytes and other protists in High Arctic lakes: molecular gene surveys, pigment signatures and microscopy. Polar Biol 35:733-748

> Church MJ, DeLong EF, Ducklow HW, Karner MB, Preston CM, Karl DM (2003) Abundance and distribution of planktonic Archaea and Bacteria in the waters west of the Antarctic Peninsula. Limnol Oceanogr 48:1893-1902

Clarke A, Murphy EJ, Meredith MP, King JC, Peck LS, Barnes DKA, Smith RC (2007) Climate change and the marine ecosystem of the western Antarctic Peninsula. Philos Trans R Soc Lond B Biol Sci 362:149-166

Colwell R (2009) EstimateS: Statistical estimation of species richness and shared species from samples. Version 8.2. http://viceroy.eeb.uconn.edu/EstimateS

Comeau AM, Li WKW, Tremblay JE, Carmack EC, Lovejoy C (2011) Arctic Ocean microbial community structure before and after the 2007 record sea ice minimum. PLoS ONE 6:e27492

> DeLong EF, Karl DM (2005) Genomic perspectives in microbial oceanography. Nature 437:336-342

DeLong EF, Preston CM, Mincer T, Rich V and others (2006) Community genomics among stratified microbial assemblages in the ocean's interior. Science 311:496-503

Ducklow HW, Myers KMS, Erickson M, Ghiglione J-F, Murray AE (2011) Response of a summertime Antarctic marine bacterial community to glucose and ammonium enrichment. Aquat Microb Ecol 64:205-220

Ducklow H, Clarke A, Dickhut R, Doney SC and others (2012a) The marine system of the Western Antarctic Peninsula. In: Rogers AD, Johnston NM, Murphy EJ, Clarke A (eds) Antarctic ecosystems: an extreme environment in a changing world. Blackwell Publishing, London, p 121-159

> Ducklow HW, Schofield O, Vernet M, Stammerjohn S, Erickson M, Sciences C, Jolla L (2012b) Multiscale control of bacterial production by phytoplankton dynamics and sea ice along the western Antarctic Peninsula: a regional and decadal investigation. J Mar Syst 98-99: 26-39 
Frias-Lopez J, Shi Y, Tyson GW, Coleman ML, Schuster SC, Chisholm SW, Delong EF (2008) Microbial community gene expression in ocean surface waters. Proc Natl Acad Sci USA 105:3805-3810

> Garibotti IA, Vernet M, Ferrario ME, Smith RC, Ross RM, Quetin LB (2003a) Phytoplankton spatial distribution patterns along the western Antarctic Peninsula (Southern Ocean). Mar Ecol Prog Ser 261:21-39

Garibotti IA, Vernet M, Kozlowski WA, Ferrario ME (2003b) Composition and biomass of phytoplankton assemblages in coastal Antarctic waters: a comparison of chemotaxonomic and microscopic analyses. Mar Ecol Prog Ser 247: $27-42$

Garibotti IA, Vernet M, Ferrario ME (2005) Annually recurrent phytoplanktonic assemblages during summer in the seasonal ice zone west of the Antarctic Peninsula (Southern Ocean). Deep-Sea Res I 52:1823-1841

> Gast RJ, Moran DM, Dennett MR, Caron DA (2007) Kleptoplasty in an Antarctic dinoflagellate: caught in evolutionary transition? Environ Microbiol 9:39-45

Gentile G, Giuliano L, D'Auria G, Smedile F, Azzaro M, De Domenico M, Yakimov MM (2006) Study of bacterial communities in Antarctic coastal waters by a combination of 16S rRNA and 16S rDNA sequencing. Environ Microbiol 8:2150-2161

> Ghiglione JF, Murray AE (2012) Pronounced summer to winter differences and higher wintertime richness in coastal Antarctic marine bacterioplankton. Environ Microbiol 14:617-629

Glöckner FO, Fuchs BM, Amann R (1999) Bacterioplankton compositions of lakes and oceans: a first comparison based on fluorescence in situ hybridization. Appl Environ Microbiol 65:3721-3726

Grzymski JJ, Riesenfeld CS, Williams TJ, Dussaq AM and others (2012) A metagenomic assessment of winter and summer bacterioplankton from Antarctica Peninsula coastal surface waters. ISME J 6:1901-1915

> Hewson I, Steele JA, Capone DG, Fuhrman JA (2006) Temporal and spatial scales of variation in bacterioplankton assemblages of oligotrophic surface waters. Mar Ecol Prog Ser 311:67-77

> Huber JA, Mark Welch DB, Morrison HG, Huse SM, Neal PR, Butterfield DA, Sogin ML (2007) Microbial population structures in the deep marine biosphere. Science 318:97-100

> Huse SM, Huber JA, Morrison HG, Sogin ML, Welch DM (2007) Accuracy and quality of massively parallel DNA pyrosequencing. Genome Biol 8:R143

Huse SM, Dethlefsen L, Huber JA, Welch DM, Relman DA, Sogin ML (2008) Exploring microbial diversity and taxonomy using SSU rRNA hypervariable tag sequencing. PLoS Genet 4:e1000255

> Huse SM, Welch DM, Morrison HG, Sogin ML (2010) Ironing out the wrinkles in the rare biosphere through improved OTU clustering. Environ Microbiol 12: 1889-1898

Landa M, Cottrell MT, Kirchman DL, Blain S, Obernosterer I (2013) Changes in bacterial diversity in response to dissolved organic matter supply in a continuous culture experiment. Aquat Microb Ecol 69:157-168

> Martinson DG, Stammerjohn SE, Iannuzzi RA, Smith RC, Vernet M (2008) Western Antarctic Peninsula physical oceanography and spatio-temporal variability. Deep-Sea Res II 55:1964-1987

Massana R, Taylor LT, Murray AE, Wu KY, Jeffrey WH,
DeLong EF (1998) Vertical distribution and temporal variation of marine planktonic archaea in the Gerlache Strait, Antarctica, during early spring. Limnol Oceanogr 43:607-617

McCliment EA, Nelson CE, Carlson CA, Alldredge AL, Witting J, Amaral-Zettler LA (2012) An all-taxon microbial inventory of the Moorea coral reef ecosystem. ISME J 6 : 309-319

Meredith MP, King JC (2005) Rapid climate change in the ocean west of the Antarctic Peninsula during the second half of the 20th century. Geophys Res Lett 32, L19604, doi:10.1029/2005GL024042

> Montes-Hugo M, Doney SC, Ducklow HW, Fraser W, Martinson D, Stammerjohn SE, Schofield O (2009) Recent changes in phytoplankton communities associated with rapid regional climate change along the western Antarctic Peninsula. Science 323:1470-1473

Mosby H (1934) Scientific results of the Norwegian Antarctic expeditions, 1927-1928, Vol. 11. Norske Videnskapelig, Oslo

Murray AE, Grzymski JJ (2007) Diversity and genomics of Antarctic marine micro-organisms. Philos Trans R Soc Lond B Biol Sci 362:2259-2271

Murray AE, Preston CM, Massana R, Taylor LT, Blakis A, Wu K, DeLong EF (1998) Seasonal and spatial variability of bacterial and archaeal assemblages in the coastal waters off Anvers Island, Antarctica. Appl Environ Microbiol 64:2585-2595

Peck JE (2010) Multivariate analysis for community ecologists: step-by-step using PC-ORD. MjM Software Design, Gleneden Beach, OR

> Piquet AMT, Bolhuis H, Meredith MP, Buma AGJ (2011) Shifts in coastal Antarctic marine microbial communities during and after melt water-related surface stratification. FEMS Microbiol Ecol 76:413-427

Pizzetti I, Fuchs BM, Gerdts G, Wichels A, Wiltshire KH, Amann R (2011) Temporal variability of coastal Planctomycetes clades at Kabeltonne Station, North Sea. Appl Environ Microbiol 77:5009-5017

> Pomeroy LR, Williams PJ, Azam F, Hobbie JE (2007) The microbial loop. Oceanography (Wash DC) 20:28-33

Pommier T, Pinhassi J, Hagström Å (2005) Biogeographic analysis of ribosomal RNA clusters from marine bacterioplankton. Aquat Microb Ecol 41:79-89

> Pommier T, Canback B, Riemann L, Bostrom KH and others (2007) Global patterns of diversity and community structure in marine bacterioplankton. Mol Ecol 16:867-880

R Development Core Team (2008) R: a language and environment for statistical computing. www.r-project.org

> Robertson GP, Collins SL, Foster DR, Brokaw N and others (2012) Long-term ecological research in a human-dominated world. BioScience 62:342-353

> Rodríguez J, Jiménez-Gómez F, Blanco JM, Figueroa FL (2002a) Physical gradients and spatial variability of the size structure and composition of phytoplankton in the Gerlache Strait (Antarctica). Deep-Sea Res II 49:693-706

Rodríguez F, Varela M, Zapata M (2002b) Phytoplankton assemblages in the Gerlache and Bransfield Straits (Antarctic Peninsula) determined by light microscopy and CHEMTAX analysis of HPLC pigment data. DeepSea Res II 49:723-747

Savidge DK, Amft JA (2009) Circulation on the West Antarctic Peninsula derived from 6 years of shipboard ADCP transects. Deep-Sea Res I 56:1633-1655

Shannon P, Markiel A, Ozier O, Baliga NS and others (2003) 
Cytoscape: a software environment for integrated models of biomolecular interaction networks. Genome Res 13:2498-2504

Smith RC, Dierssen HM, Vernet M (1996) Phytoplankton biomass and productivity in the western Antarctic peninsula region. In: Ross RM, Hofmann EE, Quetin LB (eds) Foundations for ecological research west of the Antarctic Peninsula. American Geophysical Union, Washington, DC, p 333-356

Smith RC, Baker KS, Byers ML, Stammerjohn SE (1998a) Primary productivity of the Palmer long term ecological research area and the Southern Ocean. J Mar Syst 17: 245-259

Smith RC, Baker KS, Vernet M (1998b) Seasonal and interannual variability of phytoplankton biomass west of the Antarctic Peninsula. J Mar Syst 17:229-243

Sogin ML, Morrison HG, Huber JA, Welch DM and others (2006) Microbial diversity in the deep sea and the underexplored 'rare biosphere'. Proc Natl Acad Sci USA 103: 12115-12120

Stammerjohn SE, Martinson DG, Smith RC, Iannuzzi RA (2008) Sea ice in the western Antarctic Peninsula region: spatio-temporal variability from ecological and climate change perspectives. Deep-Sea Res II 55:2041-2058

Straza TRA, Ducklow HW, Murray AE, Kirchman DL (2010) Abundance and single-cell activity of bacterial groups in Antarctic coastal waters. Limnol Oceanogr 55:2526-2536

Swan BK, Martinez-Garcia M, Preston CM, Sczyrba A and others (2011) Potential for chemolithoautotrophy among ubiquitous bacteria lineages in the dark ocean. Science 333:1296-1300

ter Braak CJF, Šmilauer P (2002) CANOCO reference man-

Editorial responsibility: Jed Fuhrman,

Los Angeles, California, USA ual and CanoDraw for Window's User's guide: software for canonical community ordination (Version 4.5). Microcomputer Power, Ithaca, NY

Tuchman NC, Schollett MA, Rier ST, Geddes P (2006) Differential heterotrophic utilization of organic compounds by diatoms and bacteria under light and dark conditions. Hydrobiologia 561:167-177

> Villafañe V, Helbling EW, Holm-Hansen O (1993) Phytoplankton around Elephant Island, Antarctica. Polar Biol 13:183-191

Wilkins D, Lauro FM, Williams TJ, Demaere MZ and others (2013a) Biogeographic partitioning of Southern Ocean microorganisms revealed by metagenomics. Environ Microbiol 15:1318-1333

> Wilkins D, van Sebille E, Rintoul SR, Lauro FM, Cavicchioli R (2013b) Advection shapes Southern Ocean microbial assemblages independent of distance and environment effects. Nat Commun 4:2457

Wilkins D, Yau S, Williams TJ, Allen MA and others (2013c) Key microbial drivers in Antarctic aquatic environments. FEMS Microbiol Rev 37:303-335

> Yilmaz P, Kottmann R, Field D, Knight R and others (2011) Minimum information about a marker gene sequence (MIMARKS) and minimum information about any $(\mathrm{x})$ sequence (MIxS) specifications. Nat Biotechnol 29: 415-420

> Yooseph S, Nealson KH, Rusch DB, McCrow JP and others (2010) Genomic and functional adaptation in surface ocean planktonic prokaryotes. Nature 468:60-66

Zhu F, Massana R, Not F, Marie D, Vaulot D (2005) Mapping of picoeucaryotes in marine ecosystems with quantitative PCR of the 18S rRNA gene. FEMS Microbiol Ecol 52: $79-92$

Submitted: August 12, 2013; Accepted: April 23, 2014 Proofs received from author(s): August 15, 2014 